\title{
The Tipikor Trial Model Based on IT In implementation of The Hearing on The Islands To Be Fast, Lightweight Cost and Simple
}

\author{
Sulistyanta ${ }^{1 *}$, Sebastianus Adi Santoso Mola ${ }^{1}$, Fredyk M Haba Djingi ${ }^{1}$, and Fatma Ayu Jati Putri ${ }^{1}$ \\ ${ }^{1}$ Faculty of Law, Nusa Cendana University, Kupang, Indonesia
}

\begin{abstract}
Based on Law no. 46 of 2009 on the Court of Corruption, this court has the authority to examine and decide on corruption cases filed by the KPK and the State Prosecutors and High Offices. According to Article 35 paragraph (1) to paragraph (4) of Law no. 46 year 2009 TIPIKOR courts exist only in each provincial capital whose jurisdiction covers the province concerned. The existence of this provision would not want the District Attorney in every district/city should delegate the case to the Corruption Court in the provincial capital. Whereas the area of NTT is an archipelago area where distance between districts with the city of Kupang is very far.

Based on the results research: the cost required by several State Prosecutors' samples to prosecute 1 (one) case in TIPIKOR Court in Kupang is quite varied, i.e. Rp.127.534.000, -, Rp. 294,096,000, -, Rp. 376,556,000, - and Rp. 354,220,000, -. The costs generally have exceeded the cost limit for the determined prosecution of Rp. 190,000,000, -. The variation of cost incurred by each State Prosecutor's sample gives an illustration that the more distance from Kupang city, the greater the cost. In addition, the duration of the ongoing trial process has had an effect on the cost. Weather factors, flight delays due to bad weather make the trial schedule chaotic, and costs incurred increases. As a result, the work of witnesses becomes neglected, the Public Prosecutor's job of handling other cases becomes impeded.

Based on the matters above, it is necessary to create a sub-district court model and/or IT-based TIPIKOR judiciary to save relatively expensive cost and cut the time available to bring it closer to the quick, cheap, and simple justice principles. This alternative judicial model of TIPIKOR in addition to contributing to the theoretical level of future development of the judicial system, is expected to become a model for the mining of the judicial system in other islands provinces in Indonesia.
\end{abstract}

\section{Introduction}

Law enforcement is a process for establishing or enforcing legal norms in a real way. Norm or kaedah is a behavioral guide in the life of society and state. The criminal law enforcement process is carried out by a system called the criminal justice system. As a system, the criminal justice system is a work mechanism undertaken by components such as police sub-systems, prosecutorial sub-systems, sub-systems of courts and sub-systems of penitentiaries. Some of these sub-systems work together to achieve goals. Justice (criminal) as a sub-system of the criminal justice system has the purpose to uphold truth and justice.

Criminal law enforcement procedures (material) are regulated in criminal law and criminal procedural law. The main source of criminal procedural law is the Criminal Procedure Code (KUHAP). In addition, there are special criminal procedural rules. Special criminal procedure law is contained in legislation outside the KUHAP and KUHP as in the Corruption Act. Thus, there is a general criminal procedural law (KUHAP) and special criminal procedural law (outside the KUHAP). In principle, it is stipulated that the generally accepted criminal procedural law (KUHAP) remain in force unless otherwise stipulated.

\footnotetext{
* Corresponding author : soelistyanta@gmail.com
} 
In connection with the judiciary, in Indonesia there are several courts such as the General Courts, State Administrative Courts, Military Courts and Religious Courts. The existence of the TIPIKOR court includes the General Court (Article 2 of Law No. 46 of 2009 on the Corruption Crime Court that the Corruption Crime Court is a special court within the General Courts).

According to Law no. 46 of 2009, corruption criminal court is a court authorized to examine and decide cases of corruption both proposed by the KPK or by the Prosecutor (State and High). Based on Article 35 paragraph (1) paragraph (4) of Law no. 46 of 2009 affirms that for the first time established in each provincial capital, whose jurisdiction covers the jurisdiction of the province concerned. With the existence of these provisions, the district attorney in every district/city should not delegate the case to the Corruption Court in the provincial capital.

The above provision poses a problem especially in the area of East Nusa Tenggara (NTT), which is a province based on the head region. NTT Province consists of 21 (twenty one) districts and 1 (one) city spread over several islands. Geographically NTT consists of several large and small islands. Large islands such as Timor, Flores and Sumba, while some other islands are relatively smaller such as, Sabu Island, Rote, Alor islands (Alor island and other small islands), Solor Islands, Adonara, Lembata, Semau Island, And others as shown in the map below:

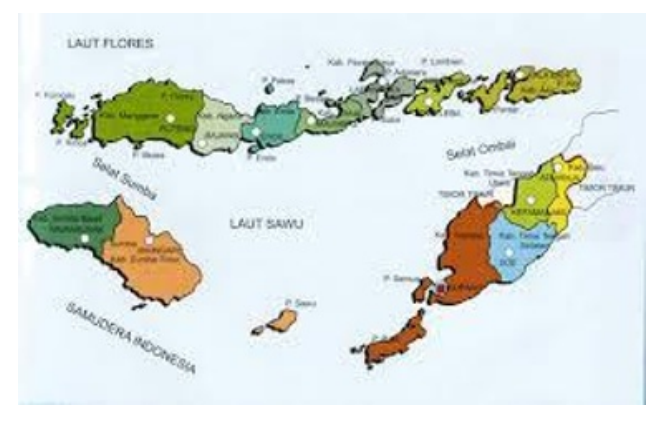

Nusa Tenggara Timur Province

In connection with the existence of the TIPIKOR court in the provincial capital raises the issue that if the District Attorney in NTT handles a case of corruption, and prosecute in the TIPIKOR trial in the provincial capital would have to travel far enough. This trip certainly cost a considerable amount. Costs include for transportation, accommodation for law enforcement, witnesses and so on. On the other hand, according to Article 50 paragraph (1) of the Criminal Procedure Code has been affirmed that one of the principles of justice is fast, simple and mild cost. The principle as a guarantee of upholding certainty, and justice.

\section{Problems}

1. Why is the judicial process of corruption in the archipelago such as NTT difficult to meet the principles of fast, low cost and simple?

2. What are the obstacles (the model court TIPIKOR) that arise in relation to the process of law enforcement of corruption in the archipelago like in NTT?

\section{Objectives of the Study}

Starting from the theoretical and problematic notion of the implementation of corruption criminal justice in the archipelago, it is hoped that there will be a solution as an IT-based sub-region model that can be a solution. The purpose of this study are: (1). Designing a judicial model of TIPIKOR based on archipelagic areas, (2). As a recommendation for future TIPIKOR judicial reforms that can meet the principle of fast, low cost and simple, especially those for the archipelago.

\section{Methodology}

This research is conducted descriptively: in the sense all, the primary data that have been collected are analyzed descriptively. The costs incurred by the state prosecutor apparatus in order to enforce the law are to demand the perpetrators of corruption in their respective jurisdictions. Location of Research: conducted at the District Attorney 
in East Nusa Tenggara Province: (1) District Court of West Manggarai, P. Flores (2) Attorney Ende, P. Flores (3) State Attorney Maumere, Sikka, P. Flores (4) Lembataa, P.Lembata, (5) Prosecutor of the State of Kalabahi, P. Alor, (6) Prosecutor of Waikabubak, West Sumba, P. Sumba (7) State Attorney of Waingapu, East Sumba, P. Sumba, and (8) State Attorney of Kefamenanu, TTU. P West Timor. Primary and secondary data collection: Secondary data collection is done by reading journals, research reports, books relevant to the research theme in the library or purchasing the required books. While the primary data retrieval (field): carried out directly to the location. Conducting interviews with appointed informants i.e. Chief Prosecutor and or representing such as, Jampidsus (Special Criminal Attorney). The interview was conducted based on the questionnaire (open). Data analysis is done descriptively: Primary data that have been collected and then done editing, coding and tabulation. The analysis is adjusted to the issues that will be answered that is related to the frequency of cases in the last 3 (three) years, the use of fees to be spent to solve a case of corruption, the time of settlement of corruption cases, the frequency of hearings conducted in TIPIKOR Court in Kupang. The data are presented in either simple or narrative frequency table included in the explanatory/analytical descriptions.

\section{Results and Discussion}

\subsection{Cost Required for Prosecution}

Based on primary data (Research Report Phase I: 2016) cost required for prosecution of 1 (one) case in TIPIKOR (corruption crime) trial in Kupang by State Attorney sample varies, that is Rp.127.534.000, -, Rp. 294,096,000, -, Rp. 376,556,000, - and Rp. 354,220,000, -. The variation in the amount of the cost is influenced by the distance, the greater the distance from the city of Kupang the greater the cost. Costs issued by the State Prosecutor's sample generally have exceeded the specified cost of prosecution cost of Rp. 190,000,000, - (each case).

Table I gives an illustration of about $80 \%$ of the cost incurred by the District Attorney to meet in the TIPIKOR Tribunal in Kupang has exceeded the prescribed fees for 1 (one) case.

Table 1. Costs issued by the District Attorney for the trial of each TIPIKOR case

\begin{tabular}{|c|l|c|}
\hline No. & \multicolumn{1}{|c|}{ Kejaksaan Negeri } & (Rp) \\
\hline 1. & Kejaksaan Negeri Manggarai Barat & 354.220 .000 \\
\hline 2. & Kejaksaan Negeri Manggarai & 193.179 .000 \\
\hline 3. & Kejaksaan Negeri Ende & $34.140 .000^{*}$ \\
\hline 4. & Kejaksaan Negeri Sikka & 376.556 .000 \\
\hline 5. & Kejaksaan Negeri Lembata & 278.554 .000 \\
\hline 6. & Kejaksaan Negeri Alor & 294.096 .000 \\
\hline 7. & Kejaksaan Negeri Sumba Timur & 186.180 .000 \\
\hline 8. & Kejaksaan Negeri Sumba barat & 127.534 .000 \\
\hline 9. & KejaksaanNegeri TTU & 191.456 .000 \\
\hline
\end{tabular}

Source of data: primary data processed, 2016 (Field Research Field Report Phase I Year 2016). Description: *) one trip during the first trial.

The prosecution of corruption criminal cases in archipelago areas such as NTT, based on economic calculations has not yet met the principles of fast, simple, and low-cost judiciary. Especially in the implementation of the trial (until the judge's decision) takes quite a long time (average 2-3 months), with a very long distance certainly add a cost. This condition is simultaneously giving an impact on law enforcement TIPIKOR.

According to the economic calculation, the cost of conducting the enforcement of the trial should be less than the financial loss of the State fought for to be returned at the hearing. Otherwise the "optimization of law enforcement will not be realized" (Mahrus Ali: 2016: 226). While economic calculations are unfavorable in law enforcement, allowing non-prosecution of the case may create a bad precedent for law enforcement itself.

\subsection{The Model Court TIPIKOR}

Based on the results of the research model is divided into 2 (two) namely model Sub Region Court TIPIKOR ITbased and model Court Sub Region Conventional. 
Model TIPIKOR Sub Region IT-Based Region and TIPIKOR Model Sub-Region Conventional Sub Region is divided into 4 (four) regions namely I P. Flores with the center of judicial activities TIPIKOR implemented in PN Ende, consisting of 8 (eight) public prosecutor's office. While the region II P. Sumba with the center of judicial activities TIPIKOR in PN Waingapu, consists of 3 (three) public prosecutor's office, region III P.Alor with the center of judicial activities TIPIKOR in PN Kalabahi, consists of 1 (one) public prosecutor's office and main area P Timor, P Sabu and P Rote-Ndao where Kupang TIPIKOR courts in Kupang are comprised of 7 (seven) public prosecutors' offices.

Model TIPIKOR Sub Region IT-Based Region and TIPIKOR Model Sub-Region Conventional Sub Region is divided into 4 (four) regions namely I P. Flores with the center of judicial activities TIPIKOR implemented in PN Ende, consisting of 8 (eight) public prosecutor's office. While the region II P. Sumba with the center of judicial activities TIPIKOR in PN Waingapu, consists of 3 (three) public prosecutor's office, region III P.Alor with the center of judicial activities TIPIKOR in PN Kalabahi, consists of 1 (one) public prosecutor's office and main area P Timor, P Sabu and P Rote-Ndao where Kupang TIPIKOR courts in Kupang are comprised of 7 (seven) public prosecutors' offices.

\section{(1) TIPIKOR TYPES of IT Sub-District Court Model:}

According to this model, the panel of judges remained at the Kupang TIPIKOR District Court in Kupang, while the Prosecutors, defendants and Legal Counsel were in each sub-region where the trial was being held. For example, the TIPIKOR trial in P.N Ende, P Flores will be connected with the panel of judges at TIPIKOR PN Kupang, Kupang through IT network in the form of video conference and teleconference.

For more details is shown below, there is a chart showing some areas of TIPIKOR courts connected to TIPIKOR Kupang District in Kupang.

Figure 1. TIPIKOR Court Model Sub Region IT-Based in Island Region

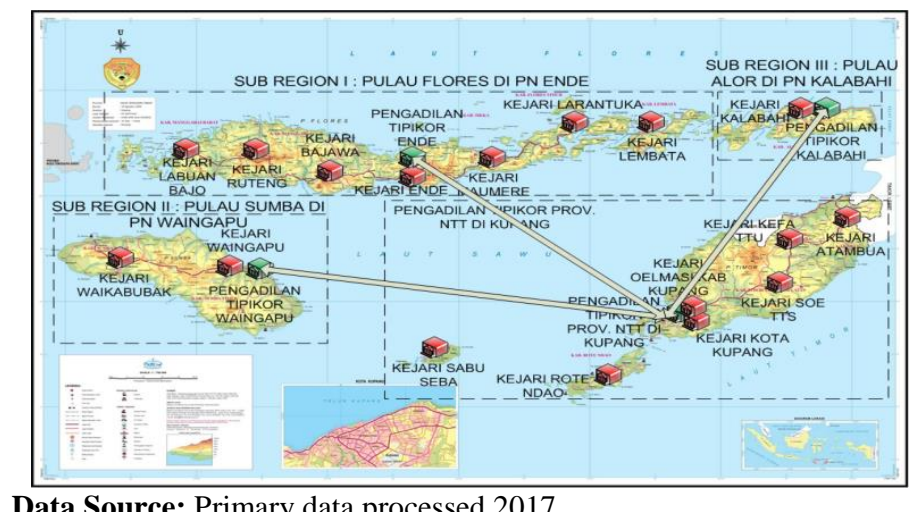

Data Source: Primary data processed 2017.

The IT-based TIPIKOR court model is connected through the use of the central IT network at PN TIPIKOR Kupang connected to 3 (three) sub-region regions.

(2) TIPIKOR MASTERED Model Based on Conventional Sub Region

The TIPIKOR courts based on the Conventional Sub Region are meant to be a TIPIKOR court as are the general courts where periodic and scheduled judges come physically to the sample district courts in the Ende District Court (P Flores), the Waingapu District Court (P Sumba) and the District Court Kalabahi (P Alor). Each TIPIKOR district court of the sample has a territory that includes several prosecutions, such as the Ende District Court, including the West Manggarai District Attorney, Manggarai District Attorney, State Prosecutor of Ende, Sikka District Attorney, East Manggarai District Court and Nagakeo District. Thus, do not use IT technology. The division of regions as illustrated in the diagram below: 
Figure 4: Court of TIPIKOR Model of Conventional Sub Region

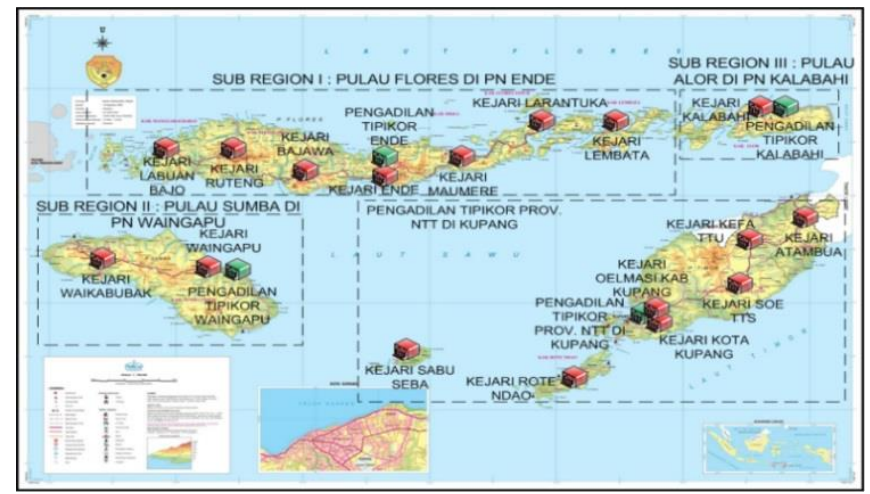

Data source: Primary data processed 2017.

The analysis of the juridical aspect, the cost-saving aspect, the application of the quick justice principle, the cheap and simple cost of using the models compared to the present where the process of corruption case investigation is still centered in TIPIKOR Court in Kupang as mentioned above.

\section{Conclusion}

a. The law enforcement becomes less optimal because with the available budget and the existing conditions could only hold a minimal law enforcement.

b. Requires technicians in the IT field at least 2 (two) persons with expertise (S1) including networking expertise and informatics engineering expertise in the new TIPIKOR courts, in order to maintain and operate the IT equipment during the trial. It is necessary to add judges especially if applied by conventional sub-district court model, because it is necessary to place at least 2 (two) Corruption judges and 2 (two) Ad hoc judges in the courts of P Flores, P Sumba and P Alor.

\section{References}

1. M. Ali, Hukum Pidana Korupsi, (UII Press, Yogyakarta, 2006)

2. M. Arto, Mencari Keadilan (Kritik Dan Solusi Terhadap Praktik Paradilan Perdata di Indonesia), (Pustaka Pelajar Offset, Yogyakarta, 2001)

3. Eriyatno, Ilmu Sistem, Meningkatkan Mutu dan Efektivitas Manajemen, (IPB Press, Bogor, 1998)

4. Ford, A. Modeling of Environment : An Introduction to Sistem Dynamics Models of Environmental Sistem. (Island Press, California, 1999)

5. L.M. Friedman, Sistem Hukum Perspektif Ilmu Sosial (The Legal System A Social Science Perspective), translated by M Khosim (Nusamedia, Bandung, 2009)

6. Y. Harahap, Kedudukan Kewenangan dan Hukum Acara Peradilan Agama, (PT Garuda Metro Politan Press, Jakarta. 1993)

7. Supreme Court Verdict No: 022/KMA/SK/II/2011 7 February 2011

8. Supreme Court Verdict No: 144/KMA/SKIVIII/2007 Year 2007

9. B. Poernomo, Pola Dasar, Teori-Asas Umum Hukum Acara Pidana dan Penegakan Hukum Pidana, (Liberty, Yogyakarta, 1993)

10. Sukardi, GLORIA YURIS, 1. 1 (2012)

11. Sawardi, J. Magister, 2.2 (2012) 
12. F. G Suratmo, Panduan Penelitian Multidisiplin, (IPB Press, Bogor, 2002)

13. Winardi. Pengantar Tentang Teori Sistem dan Analisis Sistem, (Mandar Maju, Bandung, 1999)

14. Law No. 4 Year 2004

15. Law No. 46 Year 2009

16. A. Aulawi, Jalan Panjang Menuju Akselerasi Pembangunan Daerah Kepulauan, www.Gresnews.com accesed 10-April 2015.

17. J. Asshidiqie, Reformasi Tata KelolaPeradilan at www.jimlyschool.com

18. B.A. Susilo, Peran Teknologi Informasi dalam Memodernisasi Sistem Peradilan di Indonesia at www.ptunyogyakarta.go.id

19. C. Huda, Manfaat Teknologi Keterbukaan Informasi di Situs Pengadilan Negeri Kepanjen at http://pnkepanjen.go.id di

20. S.Mafta, Elektabilitas Penerapan Asas Peradilan Cepat, Sederhana dan Biaya Ringan Terhadap Hukum Pidana, at http://matfa-setiawan.blogspot.com/2014/06/makalah-elektabilitas-penerapan-asas.html\#.VT ZF9l Hm ZQ 